\title{
5 On (not) living past 30
}

\author{
Tony E. Adams
}

In August 2001, at 22, you began to disidentify as straight and come out as gay. Having repressed same-sex attraction for several years, you began to recognise and embrace its permanence; it wasn't going to disappear, so you had better get used to it. That August, you began dating a cisgender man; the relationship ended in September. In September, you began dating another cisman but stopped in October. In November, you began dating another cisman; that relationship ended in December. The pattern continued for several months.

To complicate the entrance into gayness, you were also, simultaneously, learning about dating, pleasure, and sex. As a product (victim) of extensive Catholic education (ages 5-18), at 22 you still had never had any kind of sex. You didn't know much about sex either. You knew the primary purpose of sex was procreation (not pleasure); marriage was an institution comprised of one cisman and one ciswoman; all methods of birth control (e.g., condoms, pills) were sinful; and penis-vaginal penetrative sex occurring outside of marriage was sinful too. Masturbation was sinful as well - one shall not 'waste his seed'; you didn't learn how to masturbate until November 2001, at 22, with boyfriend three.

In August 2002, you met Brett, a new student in the same graduate programme. He was 26; you, 23. He had been out - had claimed and proclaimed his gayness - for nearly a decade; you, merely a year. You felt a strong connection to Brett and began dating within weeks of meeting. Brett quickly became a good gay friend, mentor, and lover who championed your early disclosures of gayness, especially to (former) friends and family, many of whom reacted poorly. Brett also taught you about various histories and controversies of gay life - about intimacy and commitment, marijuana, sex and pleasure, and open relationships - as well as introduced you to the works of Cher, k.d. lang, Susan Sontag, Madonna, Gus Van Sant, and Judy Garland. 
'I'll be dead by 30,' Brett often said, randomly and flippantly. 'Gays are vicious and live for youth. After 30, you won't be wanted or attractive'. ${ }^{1}$

'Nonsense', you'd say, 'age is just a number'. Sometimes, you'd quip further: 'Besides, you already look 30.'

To this, Brett would laugh, roll his eyes, offer a cutting stare or biting remark, and the conversation would end. Until a few weeks later, when he'd make the declaration again.

Although you wouldn't overtly agree with Brett in this remark, you too contributed to such ageist, specifically youthist, discourse. In your 20s, before and after Brett, on your online dating profiles, you described men over 30 as unattractive and undesirable; men over 40 - hell no. None were worthy of your attention; the aged men felt creepy, worn, desperate.

The intimate relationship with Brett ended in December 2003, yet you remained close. You continued to live together until May 2004, when he moved to New York to pursue theatre, and you moved to Tampa to pursue a doctoral programme. In December 2004, you visited Brett in a travelling theatre production at a dinner theatre in Ohio; you spent the night together at a hotel. In February 2005, you met Brett at the Tampa airport; he had a long layover and asked to meet for dinner, drinks, and laughs. You'd speak on the phone every few weeks. You left Brett a voicemail one week before he died.

Brett was born 27 August 1976. He died 28 February 2006, six months before his 30th birthday. His family reported that he died from diabetic shock - not too shocking, as he didn't monitor his blood sugar well. On some low-blood-sugar nights he would roll in bed and wake you accidentally; unconscious and covered in sweat, he wouldn't know where he was or who you were. Alongside diabetes, Brett also had a history of suicide attempts. When he died, two mutual friends reported that he had killed himself after coming out to his father. Neither the diabetes report nor the suicide report was ever confirmed. ${ }^{2}$

Here, now, you think about Brett's 'I'll-be-dead-by-30' prediction. Was his statement a foreshadowing, a plea for help - or merely a sarcastic remark

1 'I remember thinking 30 was an expiration date', Fox writes (2015, p. 239). One of Goltz's (2009) interviewees explained that in “"gay years”, 30 means you are on the way out' (p. 571). Urban Dictionary defines 'gay death' as what happens when 'a gay man turns 30', and one episode of the series Queer as Folk ('Full Circle', Cowen, Lipman \& Chapple, 2001) centred around one of the main gay character's death-themed 30th birthday party. For more comprehensive discussions of gay youthism and aging, see Bergling (2004), Goltz (2009, 2010, 2011), Harley \& Teaster (2016), Ramirez-Valles (2016), and Simpson (2015).

2 See Holman Jones and Adams (2014). 
intended to generate conversation and laughter? Did Brett plan his death - a plan easier to accomplish with suicide, less so via diabetic shock? The answer is a mystery. You only wonder why someone like Brett, a loving and jovial being, had a fear of living too long; why he subscribed to a tainted view of aging and sexuality; how he predicted a death that happened too soon. You also think about what Brett missed having not lived this long, as well as how you ever did.

The more you read and talked with gay others, the more you realised that gay aging wasn't merely an issue of youth and sexual attraction; additional constraints could contribute to a gay man's desire to die by 30 .

Maybe there were tensions with families-of-origin who, initially in life, were understood and idealised as systems of unconditional love and support. Yet, for some men, once they came out as gay, familial love and support turned conditional and disappeared. The men may have been ridiculed, disowned, cast aside ${ }^{3}$; or required to undergo conversion therapy, prayer, and a pledge of celibacy in order to retain membership in the family, continue as a family member; or exposed to more homophobic remarks, or conversely, unsettling silences about their gayness. And so, some gay men ceased contact with hateful families-of-origin. ${ }^{4}$ How might it have felt to lose a primary support system after a mere disclosure of sexuality? (It sucked.)

One of the first phrases I learned as a gay man was 'he's "family". Gay friends used the phrase to reference another's gayness:

'Do you know Tony?' one gay asks.

'Yes, why?' the other gay replies.

'He's "family"', the first gay says.

Family - a term used by some gays in reference to other gays, to determine members of the/our gay family: others to rely on for safety and support when families-of-origin fail. ${ }^{5}$

3 'Of course, heterosexuals can also be disowned', Weston (1991) writes. 'But when straight people encounter rejection by relatives, that rejection arises on a case-by-case basis, generally in response to something done rather than something fundamental to their sense of self. Self-identified lesbians and gay men, in contrast, experience rejection as an ever-present possibility structured by claiming a stigmatised sexual identity' (p. 74).

4 The entirety of Weston's classic book Families We Choose (1991) details processes and nuances of gay kinship and the development of families-of-choice. Weston also observed how a gay child, if they are the first gay in the family, might assume the sole burden of not only introducing gayness to the family, but also having to explain what it means to be gay (while simultaneously learning what gay means themselves). As such, gay men must often venture 'beyond our biological family to find our logical one, the one that actually makes sense for us. We have to, if we are to live without squandering our lives' (Maupin, 2017, p. 2). Metaphorically, 'blood' isn't always 'thicker than water', and all families should be understood as families-of-choice.

5 In The Queen's Vernacular: A Gay Lexicon (1972), Bruce Rodgers defines the gay use of 'family' as a reference to a 'close-knit group bound together by friendship rather than by 
You think about the homophobic and heteronormative religious discourse that permeated (and still permeates) US cultural life. Some religions espoused hateful mantras such as 'Love the sinner, hate the $\sin ^{9} 6$ advocated for heterosexual 'purity pledges'; ${ }^{7}$ only conducted marriages comprised of one cisman and one ciswoman; adhered to rigid cisgender roles and assumptions; praised two-parent families-of-origin (e.g., 'Honor your father and mother'); and promoted conversion therapy - therapy designed to 'cure' (or at least curtail) same-sex sexual activity. Sodomy laws criminalised samesex sexual relations - laws rooted in the biblical tale about the supposed degenerates of Sodom and Gomorrah. And even the most progressive religions advocated heteronormative values, such as monogamy, marriage, and biological reproduction, and simultaneously disavowed variations of (gay) life, such as praising sexual pleasure, refusing to conform to gender roles and expectations, living in open and polyamorous relationships, and choosing to live child-free. ${ }^{8}$

You also think about the lack of cultural narratives about gay life after 30. You knew the post-30 heterosexual scripts and trajectories - be married (or at least pursue relationships with an 'opposite-sexed' cisgender); have a kid ('start a family'); make money; have another kid; celebrate birthdays, graduations, baptisms, and bar/bat mitzvahs; have another kid; get divorced and married again; encourage your kid(s) to get married and have kid(s); attend family reunions; celebrate retirements; spend time with (take care of) grandkids. What do gays (and straights) do if these narratives don't fit??

blood-ties' (p. 79). Although the use of 'family' perpetuates the privileging of familial discourse and bias, your definition of family is very inclusive, e.g., best friends, companion animal relations, polyamorous arrangements. You are fine with celebrating the concept of 'family' as long as the concept is open, inclusive, and able to be defined by those involved.

6 As Arceneaux (2018) writes, 'If you were under the impression that being gay was inherently wrong, you were operating from the frame of mind that $I$ was inherently wrong' (p. 214). Cunningham (2014) makes a similar claim: 'Hate the sin, love the sinner sounds real good if you're on the loving end of that equation, but if you're on the sinner's side of that prayer it feels dehumanizing and condescending' (p. 53).

7 See Harris (2014) and Manning (2015).

8 Harris (2014) demonstrates how even 'progressive' religions, such as the Metropolitan Community Church and United Church of Christ, are intolerant and anti-gay in their advocacy of heteronormative values.

9 Dustin Goltz has written extensively on gay youthism, aging, and time in an attempt to 'counter limited or tragic stories of gay male aging as isolated, miserable, or depressing' (Goltz, 2011, p. xiv). In one article Goltz (2009) asks, 'What does it mean to exist in a space outside of these blueprints and images, to be denied access to the dominant scripts? What if a person peers into the future and envisions loneliness, isolation, and exclusion? How does this affect living today?' (p. 562). In his book, Goltz (2010) writes, 'Heteronormative temporal perfection tells a story of happily ever after: love conquering all, the blessed gift of children, and a guaranteed slice of the [US] American Dream. Monogamous love, marriage, and procreation provide the keys to the kingdom, the honor of respectful sexual citizenship, and identification with a future worth embracing. On the other side, there is punishment and 


\section{Tony E. Adams}

Maybe HIV/AIDS narratives prohibited gays from living, or thinking they would live, past 30; in the 1980s and 1990s, the diagnosis was often a death sentence. There also weren't many hopeful or serious narratives about gay aging; ${ }^{10}$ common gay tales spotlighted loneliness, struggle, missing youth, and they did not attend to other narratives of the future - scripts and trajectories of possibility, brilliant ones that showed how life might be for those who are estranged from family or who refused heteronormativity, monogamy, and/or biological reproduction. How could gay men conceive of the future? ${ }^{11}$ Where did (do) gays go to die?

Complicating all of these factors was a sedimented and systemic ignorance and disdain for gays. ${ }^{12}$ Gayness could affect a person's perceived competence or likability, and some gays - especially those who were out - faced incessant bullying and persecution. Perceived initially as a 'gay disease', HIV/AIDS treatments - and thus particular lives - were neglected for years. Some banned gays from teaching in primary and secondary schools, bans grounded in the homophobic belief that gays were sexual predators who preyed on children. Gay histories and experiences were absent from many archives, educational curricula, and everyday conversation. Gays could have been fired solely for being gay, arrested for committing sodomy, dishonourably discharged from the US military for engaging in same-sex relational acts (e.g., sex, marriage). You traversed this ignorance and disdain with ease to only then come out and into a youth-centric, $30=$ old (and thus nearing death), gay culture. ${ }^{13}$ You knew some straights would treat you as dead for

misery for those who fail to embrace and perform the assumed rightness of heterosexuality or fail to identify with heteronormative structures for future building' (p. 82)

10 Keith Berry writes, 'Until I was in my thirties, well after I came out of the closet, I never thought about myself in terms of a long-term future for which I had to plan. Perhaps this absence stems from the outlook I conveyed above regarding HIV/AIDS, because I did not think I would last to be a senior citizen. Or maybe it's due to the heteronormative model that continues to shape and often govern lived experience in the US today. There is no model of the LGBQ senior, at least not one widely conveyed and explored' (Berry et al., 2020, p. 152).

11 As Ramirez-Valles (2016) argues, the heteronormative 'life trajectory that we perceive as "natural" takes us from birth to schooling, adolescence, job and career, marriage, reproduction, parenthood, maybe divorce, retirement, and death' (p. 39). Queer time is 'lived outside the narrative of birth, schooling, marriage, reproduction, child bearing, and retirement' and is marked by events, such as coming out, HIV, and same-sex relationships (p. 40). For specific discussions of gay orientations to time, see Goltz (2009, 2021), Halberstam (2005), and Muñoz (1999).

12 See McIntosh (1995).

13 Although age, specifically youthism, is the focus of this chapter, age isn't the only identity that can contribute to 'social death' in the gay community. White gay cismen still shun others for their ethnicity, race, ability, size, gender, and/or serostatus, especially men who do not align with insidious White, able-bodied, thin and fit, and/or cisgender expectations for desirability and attractiveness (see Berry et al., 2020; Chuang, 2020; Eguchi and Long, 2019; Riggs, 2018). 
being gay; you didn't know some gays would treat you as dead for living too long.

Maybe 'with ease' is the wrong phrase. You too had a suicide scare in high school - a nervous breakdown of sorts, a desire to quit your desires. You told your parents you didn't feel well and demanded to see a doctor. You wanted some kind of treatment; you felt confused, peculiar, tired; hated yourself; wanted to relax, sleep, die; the unbearable weight of the everyday. ${ }^{14}$ Fearing others might learn of the mental crack, the parents got you a head scan in a nearby town. The memory of these events - a blur; you cannot recall the conversations with doctors, tests or treatments, or how and why, after this incident, you continued to try to live.

Yet, you did. And you're here, now, writing this chapter, feeling something akin to 'survivor's guilt' for living this long, longer than others living through similar conditions, sad to think about what you've done and what they weren't able to do: finish graduate school; feel loved by boyfriends; write; have sex; marry; have more sex; travel; make friends; work; play softball; create a new family. Every day feels extra, and one never knows when extra will end.

You feel privileged to have survived more than a dozen years of Catholic education; the presence and pressures of heteronormativity; burgeoning same-sex attraction; estranged families-of-origin; anti-gay religiosity; limited scripts for gay aging; pervasive disdain and neglect for gay people; a suicide scare. You think about all of the gay men who didn't survive suicide, or sexual violence, or drug abuse, or HIV/AIDS, or Covid-19. You think about those who have aged into old age, seemingly gracefully, yet behind closed doors are closeted and alone, still fearful about exposing their desire; those who were castrated, shocked, lobotomised, or victims of conversion therapy, and those who subsequently killed themselves after trying such blasphemous 'cures' for homosexuality; those killed by anti-gay hate crimes, including the 49 people killed at Pulse, a gay nightclub in Orlando, Florida

14 As queer artist 'artisthought' tweeted, 'I often think about the closet that queer kids grow up in. How it's not just passive hiding, it's traumatizing. To suppress parts of who you are, to experience your own life as an outsider, to hear the people you love hate people like you, is a trauma you carry your whole life' (20 July 2020). 


\section{Tony E. Adams}

(2016); and those who never had access to appropriate and sustained medical care, or, if they did, were forced to entrust homophobic and transphobic doctors with their lives. ${ }^{15}$ You think about all of the coming-outs that didn't happen, the pleasures cut too soon, the experiences of being proudly gay and loved for it.

Here, now, life does feel better - or rather, different. Pro-gay stories have increased in the last decade; youth seem to come out younger; gays have increased legal protections; and there are social privileges to being gay. ${ }^{16} \mathrm{But}$ still, something's off: According to the Trevor Project's 2020 U.S. National Survey on LGBTQ Youth Mental Health, 40\% of LGBTQ respondents (aged 13-24) 'seriously considered attempting suicide in the past twelve months'; $48 \%$ reported 'engaging in self-harm in the past twelve months'; $10 \%$ had undergone conversion therapy; and 29\% had experienced 'homelessness, been kicked out, or run away'. Several LGBTQ youths questioned their worth, and you wonder if living too long feels unattainable, less than ideal.

Here, now, writing as a 41-year-old gay cisman, you think about Brett's comment about dying by 30, and, more generally, about aging as a gay man. You've lived more than a decade longer than Brett. You'd tell him that your 30 s were fun and your 40s have been okay so far; that your attraction to others, and their attraction to you, didn't end - it merely changed, shifted with age; and you've become a 'daddy', a mentor of sorts, to younger gay men. You'd tell Brett about how your local gay bar hosts nights celebrating 'silver foxes' and 'DILFs' (Daddies I'd Like to Fuck) and other events for 'men over 35 and the men who love them' - all indicative of a growing zeitgeist of acceptance and support for aging gays. You'd tell Brett about your neighbours, a gay male couple in their 50s and 60s; your chosen parents; and your beautiful partner of $12+$ years. (You'd even share that, for more than half of these years together, you've lived openly non-monogamous. Brett, you imagine, would judge you, slyly and sarcastically, for once judging him for refusing monogamy.)

You'd tell Brett about iPhones and Facebook, Twitter and hashtags, sexting and selfies, Tinder and Grindr. He'd be excited to see Judy (the Judy Garland biopic), Rocket Man (the Elton John biopic), and maybe even Mamma Mia (1, not 2). He would mourn Carrie Fisher and George

15 See Raimondi (2020).

16 In 'Things I Don't Have to Do' (Chapter 5) of Living Sexuality, Keith Berry describes practices he no longer has to do as a gay man. For example, gayness allows him to do gender differently and avoid heteronormative relational scripts (e.g., asking for a 'partner's father's "hand" in marriage'; Berry et al., 2020, p. 46). 
Michael, enjoy the Tiger King, and love Lady Gaga and Taylor Swift. Even though you went to Cher's 'Farewell' tour together in 2003, you'd tell him that Cher hasn't said farewell yet; she began her 'Here We Go Again' tour in 2018.

You'd tell Brett about US legal victories in support of same-sex relationships - marriage equality, employment nondiscrimination, bans on conversion therapy - as well as the things he would still have to do as a gay man: dwell in the psychic space of being prepared to lose these victories; deal with the continued presence of a mono- and heteronormative society; be concerned about his safety. ${ }^{17}$ And although churches and states are supposed to stay separate, national debates ensue about whether 'religious freedom' grants religious organisations the right to discriminate against gay employees and customers or if the rights of gay employees and customers precede religious freedom.

You'd tell Brett that you do worry about the future - the medical care you'll need, who will care for you should you fall ill, whether you have lived a well-lived life. You have been out for nearly two decades, but relational rifts continue to plague the relationships with your family-of-origin; and although you feel loved by your partner's family, should something happen to him, you wouldn't expect them to care for you. You've developed a sizable chosen family, and you'd tell Brett about your gay Covid-19 quarantine group who spends many Fridays together, a group who frequently references the idea of 'Fruit Acres', an imagined, utopian gay senior living community. The friends' mention of Fruit Acres suggests a desire to plan for aging, something reminiscent of The Golden Girls, a desire to be campy and gay together later in life. ${ }^{18}$ You worry about having to reconnect with your family-of-origin out of a need for care, ${ }^{19}$ or ever having to move into a non-gay assisted living facility, as you imagine living and dying among similarly aged peers who may still carry the homophobic residue of their (your)

17 As mentioned in 'Things I Don't Have to Do' (Chapter 5) of Living Sexuality, Keith Berry describes practices he no longer has to do as a gay man. Conversely, in 'Things I Must Still Do' (Chapter 15), Berry describes practices he must still do as a gay man, such as hide and tone down his sexuality, as well as dwell in the material and psychic space of being prepared to lose hard-fought legal rights (Berry et al., 2020, p. 148).

18 Ramiro, in an interview for Ramirez-Valles's book, 'Queer Aging' (2016), shares a similar vision of growing old with his gay family: 'It would be nice to buy a building where everyone knows each other. Get a big building, everyone pitch in, and there's your community. It doesn't have to be all gay people. It can be family; it can be people who are supportive of each other' (p. 125).

19 The documentary A Secret Love (2020) tells the story of two lesbians, a couple of 60+ years, who lived apart from their family-of-origin and who, later in life, had to rely on one partner's family-of-origin for end-of-life care. At least as portrayed in the film, one woman's family didn't seem as supportive of, or close to, her partner. The woman's partner lived longer and had to rely on the family-in-law for care. If the family-in-law really wasn't supportive, then this would surely add an additional tragic component to the end of life. 
time..$^{20}$ It takes some folks so long to leave the closet; to think of returning to it near the end of life seems cruel.

You'd tell Brett that you try not to take everyday matters too seriously, embrace irreverence, and poke fun at social mores, often to the chagrin of others. The ensuing laughter carries you through those hopeless days, soothes the pain of not feeling good enough. You wish more people - yourself included - recognised their beauty and worth, and you try to shower others with support and love, tell them that you appreciate them, and, to borrow the words from a gay friend and mentor, that you are 'glad they were born'. ${ }^{21}$

You'd tell Brett you're still friends with many mutual friends. You all talk about him and miss him very much - those cutting stares and biting remarks; the resolute friendship; of being able to call or text, or hear his voice, or see his smile. Your gay life didn't end at 30, and you wish his hadn't either. If he was here, now, you'd tell him that gayness - his gayness - is beautiful; that you love him for loving young gay you; that you are indeed glad he was born.

You finish this chapter in Covid-19 quarantine. For months, you have worried about contracting the virus, getting sick, dying. If you did get sick, you'd think about what you were (not) able to do, about no longer having moments of joy: of being with friends family at a local gay bar; dancing and singing and enjoying draft beer; laughing with each other; saying 'we're still here', 'it's been a good life', and maybe even 'we survived'. You all have survived - survived homophobic families-of-origin, religions, governments; the anxieties of youth; suicide scares; pressure to reproduce, of being taught the primary purpose of life is to make children who make children who make children. You reminisce about past heartaches, relationships lost and gained and lost again, the many others who died innocent and young; and the gratitude you feel for making it this far. You're past 40 and 50 isn't far away. At 60 , and then 70 , and then 80 , you hope to meet at a gay bar with your family, hope to say, again, 'we're still here', 'it's been a good life', and maybe even 'we survived'. Death is inevitable, but you're thinking too much and too far ahead, about factors and situations about which you have little direct control. Here, now, you feel okay; you have a drive to live and still some dancing and loving to do. ${ }^{22}$

20 See White and Gendron (2016) and Wolfenson (2017).

21 Friend, colleague, and gay mentor, Bernie Brommel, would tell you this often. He'd also often ask if you had at least one person tell you they loved you that day. If no one had told you, he sure would.

22 And just to be clear - you too are glad you were born. 


\section{Postscript: On writing 'On (not) living past 30'}

You wrote these reflections to record moments of aging, resilience, and pride, as well as to provide an account of one gay life (two, if you count Brett) as it has progressed through time.

You wrote these reflections to honour gay friends and family, as well as those lost to homophobia, despair, hopelessness, and undesirability.

You wrote these reflections to challenge heteronormative relational expectations, expand definitions of family, and conceive of and embody new scripts for aging while/as gay.

You wrote these reflections as a treatise of support, a pledge to live, and to demonstrate that gay life after 30 is possible, pleasurable.

You wrote these reflections to encourage current and future gays to live and love each other more, likely in ways different than described, but living and loving nonetheless.

\section{Acknowledgements}

I thank Keith Berry, Carolyn Ellis, Edgar Rodriguez-Dorans, Jason Holmes, and Gerardo Moreno for their feedback on this chapter.

\section{References}

Arceneaux, M. (2018). I can't date Jesus: Love, sex, family, race, and other reasons I've put my faith in Beyoncé. Atria.

Bergling, T. (2004). Reeling in the years: Gay men's perspectives on age and ageism. Harrington Park Press.

Berry, K., Adams, T. E., \& Gillotti, C. (2020). Living sexuality: Storying LGBTQ relationships, identities, and desires. Brill I Sense.

Chuang, A. K.-C. (2020). A local gay man/tongzhi or a transnational queer/quer/kuer: (Re)organizing my queerness and Asianness through personal reflection. In S. Eguchi, B. M. Calafell, \& S. Abdi (Eds.), De-whitening intersectionality: Race, intercultural communication, and politics (pp. 101-118). Lexington.

Cowen, R., Lipman, D.. (Writers) \& Chapple, A. (Director). (2001, June 17). Full circle [Television series episode]. In Cowen, R.. \& Lipman, D. (Creators), Queer as Folk. Showtime.

Cunningham, S. (2014). How we sleep at night. Sara Cunningham.

Eguchi, S. \& Long, H. R. (2019). Queer relationality as family: Yas fats! Yas femmes! Yas Asians! Journal of Homosexuality, 66(11), 1589-1608. doi: 10.1080/00918369.2018.1505756

Fox, R. (2015). Gray's anatomy. In D. B. Goltz \& J. Zingsheim (Eds.), Queer praxis: Questions for LGBTQ Worldmaking (pp. 239-240). Peter Lang.

Goltz, D. (2009). Investigating queer future meanings: Destructive perceptions of "the harder path." Qualitative Inquiry, 15(3), 561-586. doi: 10.1177/1077800408329238

Goltz, D. B. (2010). Queer temporalities in gay male representation: Tragedy, normativity, and futurity. Routledge. 
Goltz, D. B. (Ed.). (2011). Our legacies: Writings from Chicago's older gay men. iUniverse.

Goltz, D. B. (2021). Queer generativity: Temporal collisions of Fred Astaire's Dancing Lessons. Text and Performance Quarterly. https://doi.org/10.1080/1 0462937.2021 .1915496

Halberstam, J. (2005). In a queer time and place: Transgender bodies, subcultural lives. New York University Press.

Harley, D. A. \& Teaster, P. B. (Eds.). (2016). Handbook of LGBT elders: An interdisciplinary approach to principles, practices, and policies (pp. 417-437). Springer.

Harris, W. C. (2014). Slouching towards gaytheism: Christianity and queer survival in America. SUNY Press.

Holman Jones, S. \& Adams, T. E. (2014). Undoing the alphabet: A queer fugue on grief and forgiveness. Cultural Studies $\leftrightarrow$ Critical Methodologies, 14(2), 102110. doi: $10.1177 / 1532708613512260$

Manning, J. (2015). Paradoxes of (im)purity: Affirming heteronormativity and queering heterosexuality in family discourses of purity pledges. Women's Studies in Communication, 38(1), 99-117.

Maupin, A. (2017). Logical family: A memoir. Harper Perennial.

McIntosh, P. (1995). White privilege and male privilege: A personal account of coming to see correspondences through work in Women's Studies. In C. P. Harvey \& M. J. Allard (Eds.), Understanding diversity: Readings, cases, \& exercises (pp. 130-139). HarperCollins.

Muñoz, J. E. (1999). Disidentifications: Queers of color and the performance of politics. University of Minnesota Press.

Raimondi, G. A. (2020). Looking at/to/for my (oppressed/oppressor) body: A trajectory through performance autoethnography. Journal of Autoethnography, 1(3), 252-264. doi: 10.1525/joae.2020.1.3.252

Ramirez-Valles, J. (2016). Queer aging: The gayby boomers and a new frontier for gerontology. Oxford University Press.

Riggs, D. W. (2018). The psychic life of racism in gay men's communities. Lexington.

Rodgers, B. (1972). The queen's vernacular: A gay lexicon. Straight Arrow Books.

Simpson, P. (2015). Middle-aged gay men, ageing and ageism: Over the rainbow? Palgrave Macmillan.

Trevor Project. (2020). 2020 national survey on LGBTQ youth mental health. Accessed July 15, 2020 from https://www.thetrevorproject.org/survey-2020/

Weston, K. (1997).Families we choose: Lesbians, gays, kinship. Columbia University Press.

White, J. T. \& Gendron, T. L. (2016). LGBT elders in nursing homes, long-term care facilities, and residential communities. In D. A. Harley \& P. B. Teaster (Eds.), Handbook of LGBT elders: An interdisciplinary approach to principles, practices, and policies (pp. 417-437). Springer.

Wolfenson, D. H. (2017). The risks to LGBT elders in nursing homes and assisted living facilities and possible solutions. Tulane Journal of Law and Sexuality, 26, 123-131. 